\title{
Debut
}

\section{The Accession of Macedonia to the North Atlantic Treaty Organization as a Multi-Level Game ${ }^{1}$}

\author{
M. Prikolota, I. Krylov
}

Maksim Prikolota, Graduate Student, Department of Political Science in European University at St. Petersburg; 6/1 Gagarinskaya Ulitsa, St. Petersburg, 191187, Russian Federation; E-mail: mprikolota@eu.spb.ru

Ivan Krylov, Graduate Student, The Faculty of Political Science in Saint Petersburg State University; 7-9 Universitetskaya naberezhnaya, St. Petersburg, 199034, Russian Federation; E-mail: ivanich-ioda@mail.ru

\begin{abstract}
This article analyzes Macedonian foreign policy during the process of joining the North Atlantic Treaty Organization (NATO). We use a modified version of Robert Putnam's multi-level game concept to show the role of domestic actors in determining Macedonian foreign policy. Based on an analysis of the interactions between the main domestic actors, we identify the reasons for the rapid resolution, after a long pause, of the question of Macedonia's name and membership in NATO. We use a case-study approach and analyze the available data on the ratio of actors within the existing institutions, key events in the political struggle, and programmes through which the parties formulated foreign policy options. Further, we note the reasons for Greece's concessions using the concept of multi-level games. We identify a number of important conditions for the formulation of Greece's position: it is important which party controls the cabinet, whether ruling party coalition partners are ready to support the actions of the cabinet, and whether the actions of the cabinet meet the ideological expectations of other parties. We conclude that three simultaneous conditions made it possible for Macedonia to presently be on the verge of accession to NATO. First, Macedonia's cabinet was formed by a party ready to accept Greece's conditions. Second, the party opposed to the country's renaming occupied less than one third of the seats, making a constitutional majority in the assembly possible. Third, because Macedonian bloc alliances are weak, allies of the anti-renaming party were willing to go against the party forming the bloc.
\end{abstract}

Key words: foreign policy; Greece; multi-level game; Macedonia; NATO

For citation: Prikolota M., Krylov I. The Accession of Macedonia to the North Atlantic Treaty Organization as a Multi-Level Game. International Organisations Research Journal, vol. 15, no 1, pp. 177-189 (in Russian and English). DOI: 10.17323/1996-7845-2020-01-08.

\section{Introduction}

Macedonia has sought to join the Euro-Atlantic integration for many years, but unlike other post-socialist countries, it faced more than economic obstacles in doing so - the country's very

${ }^{1}$ We are grateful to Y. Agafonov, Senior Lecturer of the Department of Comparative Political Studies at the NWIM in RANEPA, for his valuable advice and guidance. 
name became the subject of international dispute. Previously, the position taken by Greece had threatened Macedonia's accession to the United Nations (UN); despite this, Macedonia has been cooperating with the North Atlantic Treaty Organization (NATO), steadily advancing since 1995 toward membership. However, while Macedonia seemed to have done everything necessary to join the Alliance in 2008, Greece vetoed the decision to invite Macedonia to sign the treaty due to problems with its name. It was only in 2018 that Macedonia and Greece began to discuss this issue, leading finally to an invitation to Macedonia to join the Alliance under a new name in 2019. How can we explain such a quick resolution of a problem that seemed unsolvable for 10 years? Why is the membership of Macedonia in NATO possible right now?

Studies of Macedonia's trajectory toward NATO and the European Union (EU) focus on the influence of the EU [Mavromatidis, 2010] and Greece [Tziampiris, 2012] and are not concerned with the joint influence of Greek and Macedonian domestic actors on this process. Therefore, in order to answer the research question, we turn to Robert Putnam's two-level games concept [Putnam, 1988]. Its essence is that the actors of international relations are not monolithic, and that there are no national interests common to all of the interest groups in a country. There are many actors in every country and the results of negotiation may depend on the coordination of interests between them. Therefore, the heads of states are forced to "play" on two levels at once. The first level involves direct negotiation between representatives of states. At the second level negotiations unfold within a country to find an agreement that takes into account the interests of groups. The fate of the ruling circles and the agreement under discussion depends on the reconciliation of these interests. The win-set is determined by the number of concessions the actors on the second level are ready to make. An agreement between states can be concluded only when the win-sets of both countries intersect, that is, when they do not encroach on the interests of the key domestic actors in each state.

Many researchers have modified Putnam's concept, considering new levels in their analyses of the formation of win-sets due to the increasing role of transnational corporations [Chung, 2007] and international organizations [Panke, 2013], particularly in the resolution of internal conflicts [Kubicek, 1997]. We also use a modified version of Putnam's concept. In this investigation, Macedonia and NATO are taken as first-level actors because they directly enter into the formal process of negotiations. Second-level actors include NATO states and the Macedonian parliamentary parties. The Greek parliamentary parties seem to be third-level actors in the win-set formation because Greece is the single NATO member that could not have formed the win-set, as we are going to show below.

\section{Background of the Agreement}

In 1991, the Republic of Macedonia emerged following the Yugoslavian collapse. However, the Republic was able to join the United Nations (UN) only in 1993 under a temporary name - the Former Yugoslav Republic of Macedonia - because the name of the new state was perceived by Greece as an encroachment on its eponymous territory. Macedonia has been seeking to join NATO since 1994 [Koloskov, 2013, p. 145] due to the Alliance's interest in stabilizing the situation in the Balkans and expanding its influence (for example, using Macedonian airspace [Ibid., p. 148]), and also due to Macedonia's desire to stabilize the situation after the events of 2001 [Ponomareva, 2010, p. 89]. In 2008, a series of actions Macedonia and NATO led to the plan to invite Macedonia to sign the joining agreement, but Greece stopped this process (although there are versions according to which the U.S. had an opportunity persuade Greece to concede [Nikovskij, 2016, p. 153] but empirically it is difficult to verify). NATO agreed that Macedonia would receive an invitation after resolving the dispute over its name. It was not 
until 2018, after numerous consultations, that the prime ministers of Macedonia and Greece concluded an agreement near Prespa Lake: Greece would withdraw its objections to Macedonia about its name provided that the Republic of Macedonia renamed itself as the Republic of North Macedonia. After this, Macedonia would be able to receive an invitation to join NATO and intensify negotiations with the EU [European Commission, n. d.].

Although resolution of the dispute over Macedonia's name was the main point of the agreement, it also satisfied other Greek requirements involving, for example, securing border inviolability and the renunciation of territorial claims. Furthermore, a number of points were devoted to symbolic policy: the content of Macedonian school textbooks would be put under the control of a bilateral commission, ancient monuments would be recognized as part of the Greek heritage, and Macedonia would refrain from using the symbols of Greek Macedonia [Hellenic Republic, 2018].

Although there were a number of concessions to Macedonia (its inhabitants are officially recognized in the agreement as Macedonians, and their language as Macedonian) the agreement became an occasion for confrontation within Macedonia. Its ratification not only required a majority of the assembly, but also the approval of the president - who refused to sign it. The presidential veto was overcome by a second vote of the assembly (70 out of 120 members of parliament (MPs)) due to its constitutional rights, and the agreement was ratified without a presidential signature [Assembly of the Republic of North Macedonia, 2018a].

The parliamentary majority decided to strengthen its position by holding a referendum on 30 September 2018. The results were controversial. On the one hand, almost every respondent voted in favour of the agreement with Greece, but on the other hand, the turnout was only 36.9\% [Republic of Macedonia, 2018]. Thus, according to Macedonian laws, the referendum failed. A survey by the Macedonian Center for International Cooperation showed that a significant part of the citizenry was dissatisfied: respondents were asked to give their opinion on Macedonia's accession to the EU and NATO through the Greece-Macedonia agreement. The survey showed that $37.5 \%$ of respondents completely disagreed with such conditions for joining [Kržalovski, 2018, p. 18]. Despite large-scale protests, on 11 January 2019 the assembly adopted a decision to amend the constitution regarding the country's name in case of ratification of the agreement by Greece (81 MPs) [Assembly of the Republic of North Macedonia, 2019]. On 6 February the protocol on Macedonia's accession to NATO was signed [NATO, 2019a], and on 12 February, after ratification by Greece, the Prespa Agreement was implemented. The official accession of North Macedonia to NATO will take place after the ratification of the protocol by all members.

\section{NATO and Greece: Second Level}

The main condition for NATO's win-set formation is the absence of opposition to Macedonia's membership by existing members other than Greece. Thus, meeting Greece's demands is the main condition for Macedonia's successful accession to NATO.

The consent of all members is necessary to form a minimal win-set on the issue of new members due to the institutional design of NATO's decision-making process. In 1999, the criteria for states seeking to join were formulated to reduce the costs of forming a large win-set every time. However, in the present case the requirements of one of the members were stricter: Greece's minimum requirement was always that Macedonia must change its name; the range and severity of additional conditions depended on who controlled the Greek cabinet.

When the agreement was signed, the Coalition of the Radical Left (SYRIZA), with 144 out of $300 \mathrm{MPs}$, and the party of the Independent Greeks (ANEL), with $10 \mathrm{MPs}$, formed the 
Greek cabinet. One of the points of ANEL's programme was "unconditional rejection of any negotiations on the name of Skopje. The name of Macedonia should not be assigned to anyone..." [Anexartitoi Ellines, 2013, p. 3]. Thus, there was an ideological gap which made it difficult to achieve a win-set for the ratification of the agreement despite the fact that two MPs from ANEL went against the party's will (given that the incumbent foreign and defence ministers represented this party).

The New Democracy party and the Panhellenic Socialist Movement (PASOK) which had formed the previous cabinets, as well as other parties, did not support the agreement with Macedonia mainly due to its recognition of the inhabitants of their northern neighbour as Macedonians and their language as Macedonian. According to them it could have negative economic and geopolitical consequences for Greece. As noted by an MP from PASOK, "the Prespa Agreement gives the Macedonian national identity to the country which has nothing in common with Macedonia. It commits a false 'ethnogenesis"' [Tzelepis, 2019]. The head of the New Democracy party similarly observed: "Who votes for [the agreement] opens the way for the supposedly 'Macedonian' identity and the language for the neighbours according to the Prespa Agreement. Those who vote 'Yes' approve of this humiliation of democracy" [Mitsotakis, 2019]. It is difficult to estimate how the points of view of the SYRIZA faction and the opposition were endogenous, given the fact the cabinets under the leadership of these parties showed both flexible and rigid positions (Table 1). For example, it would difficult to predict the behaviour of opposition parties if they formed the cabinet. It is not obvious how they would behave in the existing socio-economic conditions, which were largely dependent on the decisions of the international community, nor if their position would be so unambiguous during a period not leading up to elections. The Potami party was the only parliamentary opposition party that supported the agreement [Theodorakis, 2019]. But, as with ANEL, there was a split. Only five of 11 Potami MPs voted for ratification. As a result, the agreement was ratified by 153 votes (all of the MPs from SYRIZA, two from ANEL, five from Potami, and two from other factions) [Hellenic Parliament, 2019, pp. 3231-4].

In Greece, win-set formation primarily depended on the cabinet party's softness about Macedonia and whether the party's partners were willing to share its position. If they were not ready, the fate of the win-set would depend on the principal supporters of the agreement from the parliamentary opposition and their individual MPs, which is important in the context of the prospect for re-election. The deciding votes were given by ANEL and the Potami factions, which scored the win-set from Greece.

Table 1. Greek Foreign Policy With Regard to Macedonia

\begin{tabular}{|c|l|l|}
\hline Period & \multicolumn{1}{|c|}{ Ruling Party } & \multicolumn{1}{|c|}{ Greek Actions With Regard to Macedonia } \\
\hline $1990-1993$ & New Democracy & $\begin{array}{l}\text { The beginning of the conflict; the dispute over the name of } \\
\text { Macedonia in the UN; a compromise decision on a temporary name }\end{array}$ \\
\hline $1993-2004$ & PASOK & The embargo on Macedonia; the preliminary agreement in New York \\
\hline $2004-2015$ & New Democracy & $\begin{array}{l}\text { Freezing cooperation; blocking Macedonia's entry into NATO; joint } \\
\text { consultations since 2012 }\end{array}$ \\
\hline Since 2015 & SYRIZA + ANEL & Agreement at Prespa Lake \\
\hline
\end{tabular}

Source: Compiled by the authors based on data from the ministries of foreign affairs of North Macedonia [Republic of North Macedonia, n. d.] and Greece [Hellenic Parliament, n. d.; Hellenic Republic, n. d.]. 


\section{Macedonia: Search for a Constitutional Majority}

Because Macedonia is a parliamentary republic, parties can be considered second-level actors. In order for the Macedonian and NATO (Greek) win-sets to converge, a change of Macedonia's name and a number of concessions by Macedonia in the symbolic policy were necessary. This required amendments to the Macedonian constitution, which can be adopted by a twothirds majority ( 80 out of $120 \mathrm{MPs}$ ). In order to test the assumption that the results of negotiations depend on the balance of political forces in the assembly, it is essential to determine what position the key political forces held, and what influence they had.

The first important condition of the negotiation's effectiveness was the control of the cabinet by a party ready to meet Greek demands; that is, the prime minister needed to be from the party in support of renaming the country for the sake of joining NATO. Otherwise even the initiation of agreements would have been impossible.

The attitude of two key political forces, the Internal Macedonian Revolutionary Organization (VMRO) and the Social Democratic Union of Macedonia (SDSM), regarding Macedonia's accession to NATO can be seen in their programmes.

Both parties agreed Macedonia should be a member of NATO. Thus, the SDSM assumed that "membership in NATO and the EU is our strategic responsibility" [SDSM, 2017, p. 11]. The VMRO had a similar position, stating that "the membership of the Republic of Macedonia in the European Union and NATO remains the main foreign policy goal of the VMRODPMNE and the strategic priority of the state" [VMRO-DPMNE, 2017, p. 294]. The commitment of both major parties to Euro-Atlantic integration was also evidenced by the fact that the third significant party, the Democratic Union for Integration, had been a member of the ruling coalitions of both parties since 2002 [Assembly of the Republic of North Macedonia, 2016]. Table 2 shows the agreements between Macedonia and NATO which were concluded during the time of both the VMRO and SDSM cabinets. The minimal win-set requirements of both sides should have coincided when Macedonia began to meet the membership criterion, all other things being equal.

Nevertheless, Greece's position modified this model, making it more difficult to form a win-set in Macedonia. Looking at the party programmes, we observe that the VMRO was not ready to make these concessions: "the VMRO-DPMNE will not agree to change the constitution in order to change the constitutional name of the Republic of Macedonia" [VMRODPMNE, 2017, p. 295]. While the VMRO devoted a sub-chapter of its political programme to the issue of the dispute with Greece, the SDSM mentioned this conflict only in one sentence: "it [the consensus in society] will be called upon to overcome the dispute imposed by Greece but will not accept any talk about identity issues. The citizens will be consulted about the possible solutions" [SDSM, 2017, p. 12]. The position of the SDSM was less unambiguous than the VMRO's requirements, possibly indicating that the SDSM was ready to make bigger concessions.

Indeed, the VMRO controlled the cabinet when the question of the country's name threatened NATO membership. This caused Macedonia's membership in NATO to be postponed for 10 years: the VMRO formed a coalition in the cabinet from 2006-16. Nevertheless, despite the fact that the Prespa Agreement was signed (June 2018) a year and a half after the SDSM came to power, the VMRO's inability to form the cabinet did not explain the formation of a win-set ( 80 votes out of 120 are needed).

The second win-set condition in Macedonia was that consistent opponents of the renaming could not have more than a third of the seats in the assembly (that is, fewer than 40 seats). There is proportional representation electoral system in Macedonia divided into districts, and it is possible to form party blocs before elections, with small parties joining coalitions of the two 
Table 2. Correlation of the Possibilities Between Win-Set Formation in Macedonia and the Process of Joining NATO

\begin{tabular}{|c|c|c|c|c|c|}
\hline \multirow[t]{3}{*}{ Position } & \multirow{2}{*}{\multicolumn{2}{|c|}{$\begin{array}{c}\text { VMRO } \\
\begin{array}{l}\text { For NATO membership, against } \\
\text { the name change }\end{array}\end{array}$}} & \multirow{2}{*}{\multicolumn{2}{|c|}{$\begin{array}{c}\text { SDSM } \\
\begin{array}{c}\text { For NATO membership even } \\
\text { at the cost of changing the } \\
\text { country's name }\end{array}\end{array}$}} & \multirow[t]{3}{*}{ Results } \\
\hline & & & & & \\
\hline & Faction & Coalition & Faction & Coalition & \\
\hline 1990-94 & 38 & - & 31 & Ruling (60) & - \\
\hline 1994-98 & - & - & 63 & Ruling (87) & $\begin{array}{l}1995 \text { - Partnership for } \\
\text { Peace }\end{array}$ \\
\hline $1998-2002$ & 49 & Ruling (73) & 28 & - & $\begin{array}{l}1999 \text { - the Membership } \\
\text { Action Plan }\end{array}$ \\
\hline $2002-06$ & 10 & 23 & 38 & Ruling (62) & \multirow{2}{*}{$\begin{array}{l}2002-14-\text { participation in } \\
\text { NATO operations }\end{array}$} \\
\hline $2006-08$ & 40 & Ruling (63) & 21 & 32 & \\
\hline $2008-11$ & 52 & Ruling (63) & 18 & 27 & $\begin{array}{l}2008 \text { - the failed invitation } \\
\text { to join NATO }\end{array}$ \\
\hline $2011-14$ & 47 & Ruling (66) & 29 & 42 & $\begin{array}{l}2013 \text {-NATO military } \\
\text { instructors in Skopje }\end{array}$ \\
\hline $2014-16$ & 51 & Ruling (80) & 24 & 34 & - \\
\hline $2016-20$ & 36 & 51 & 35 & Ruling (62) & 2018 - Prespa Agreement \\
\hline
\end{tabular}

Source: Compiled according to data from the Assembly of the Republic of North Macedonia [2016] and NATO [2019b].

largest parties. This allows large parties to get the votes of national minorities and local nonparty leaders, while small parties and independents can get into the assembly without formal obligations to the rest of the coalition. Therefore, despite the fact that the VMRO coalition won 51 seats (almost 43\%), members of the party that formed the electoral bloc had only 36 seats, less than one third. However, although the core members of the VMRO won fewer than 40 seats, the VMRO electoral bloc won more than 40.

This leads to the third condition for win-set formation - the readiness of VMRO's allies in the electoral bloc to support the agreement. The SDSM managed to get 81 votes: seven independent MPs from the VMRO coalition, as well as one each from the Socialist party, the Civil Option party, and the Roma, Turkish, and Bosnian parties voted for the amendments. All nonaligned parties, including three Albanian parties, also unanimously voted for the amendments [Assembly of the Republic of North Macedonia, 2019].

The described behaviour of MPs toward their coalitions is not unique in the Macedonian assembly. Table 3 demonstrates how MPs voted on the issue of ratification of the agreement (which required a simple majority), on the issue of amendments (which required a two-thirds majority), and on the adoption of a law that would make Albanian a second official language, taking into account the partisanship and attitude to the electoral blocs. The example of the languages law reflects MPs' low degree of loyalty to their blocs and sometimes to their parties this is typical not only of the voting on the current issue in which the ruling coalition could use informal mechanisms of influence. This example shows that representatives of both blocs may vote against the will of the corresponding bloc majority (or abstain from voting), and that this pattern is not exclusive to the assembly. 
Although informal mechanisms for attracting MPs by the cabinet's party may have taken place, the low degree of the MPs' loyalty to electoral blocs also played a role in a win-set formation and made it easier for the ruling party. It is likely that these mechanisms were aimed at independent deputies from the VMRO bloc, including representatives of national minorities who had previously demonstrated their disloyalty to the bloc.

Thus, the reason for the win-set formation was not only that the VMRO had lost control of the cabinet. A key factor was that this party did not win enough seats to prevent the change in the constitution. In this case, the win-set formation depended mainly on independent MPs and representatives of national minorities from the VMRO electoral bloc.

\section{Summary}

This analysis demonstrates that several circumstances made it possible for Macedonia to join NATO at this moment in particular. The multi-level game concept reveals the role of political parties in both countries in regard to this issue. In Greece, SYRIZA took the softest position among the major parties, alienating its coalition allies while attracting principled supporters of the agreement with Macedonia.

Table 3. Votes by Macedonian MPs on the Status of the Albanian Language, the Ratification of Agreements With Greece, and the Name of the Country

\begin{tabular}{|c|c|c|c|c|c|c|c|c|}
\hline \multirow[t]{2}{*}{ Bloc } & \multirow[t]{2}{*}{ Party } & \multicolumn{3}{|c|}{$\begin{array}{l}\text { The Law on the Use of Languages } \\
\text { (14 March 2018) }\end{array}$} & \multicolumn{2}{|c|}{$\begin{array}{l}\text { The Ratification of the } \\
\text { Prespa Agreement } \\
\text { (5 July 2018) }\end{array}$} & \multicolumn{2}{|c|}{$\begin{array}{l}\text { The Third Reading } \\
\text { on the Constitutional } \\
\text { Amendments on the } \\
\text { Name of the Country } \\
\text { (11 January 2019) }\end{array}$} \\
\hline & & Agree & Not voted & Absent & Agree & Absent & Agree & Absent \\
\hline \multirow[t]{8}{*}{ VMRO } & VMRO & & 34 & 2 & & 36 & & 36 \\
\hline & Socialist & & 2 & 1 & & 3 & 1 & 2 \\
\hline & $\begin{array}{l}\text { Democratic Party } \\
\text { of Serbs }\end{array}$ & & 1 & & & 1 & & 1 \\
\hline & $\begin{array}{l}\text { Association of the } \\
\text { Bosnian Cultural Union }\end{array}$ & & & 1 & & 1 & 1 & \\
\hline & Civil Option & & 1 & & & 1 & 1 & \\
\hline & Democratic Party & 1 & & & 1 & & 1 & \\
\hline & Roma Alliance & 1 & & & 1 & & 1 & \\
\hline & Independent & 1 & 1 & 5 & 1 & 6 & 7 & \\
\hline SDSM & SDSM and others & 44 & 5 & & 49 & & 49 & \\
\hline \multicolumn{2}{|c|}{$\begin{array}{l}\text { Democratic Union for Integra- } \\
\text { tion }\end{array}$} & 10 & & & 10 & & 10 & \\
\hline \multicolumn{2}{|c|}{ Besa Movement } & 4 & 1 & & 4 & 1 & 5 & \\
\hline \multicolumn{2}{|c|}{ Alliance for Albanians } & 2 & 1 & & 2 & 1 & 3 & \\
\hline \multicolumn{2}{|c|}{ Democratic party of Albanians } & 1 & & 1 & 2 & & 2 & \\
\hline
\end{tabular}

Source: [Assembly of the Republic of North Macedonia, 2018a; 2018b; 2019]. 
In Macedonia, key political forces considered joining NATO to be justified. The nationalist VMRO party declared that renaming the country for this purpose was unacceptable while the Social Democrats considered that this would be a justifiable sacrifice. The VMRO formed the cabinet until 2017, so there was no question of renaming the country before then. However, after the elections in 2016 the coalition created by the SDSM formed a cabinet that made it possible to conclude the agreement with Greece on the least-stringent terms, and to ratify it. But the required two-thirds majority in the assembly to change the country's name could only be won due to the low degree of loyalty shown by MPs to pre-election coalitions and, probably, informal mechanisms of influence on opposition MPs.

Thus, in order for Macedonia to join NATO it was necessary that supporters of the leaststringent conditions should control the Greek cabinet and, in the case of a defection of allies, that they could rely on those who would have voted for the agreement anyway. In Macedonia, it was necessary that opponents of renaming the country (the VMRO) were not able to form the cabinet and won less than a third of the seats in the assembly, even if their electoral bloc won more. The last and decisive condition was the readiness of a sufficient number of nationalist coalition allies, mostly non-party ones, to cooperate with the Social Democrats. This readiness was probably due to the low degree of loyalty to the electoral blocs and parties on the part of MPs, and informal mechanisms of influence on them by the ruling coalition.

Because this article deals with three levels of win-set formation we believe it can help expand the space for modification of the multi-level game concept. In particular, the study demonstrates that actors at different levels can interact with each other directly to form a winset, ignoring higher levels (in the end, Macedonia negotiated with Greece in order to conclude a treaty with NATO). This article can help to shed light on the interaction between actors at different levels, for example, between a state on the one hand and an international organization on the other

\section{References}

Anexartitoi Ellines (2013). Kybernitiko programma Anexartiton Ellinon. Enotita B'. Tomeas Exoterikon [Government Programme for Independent Greeks. Section B. External Relations]. Athens: Anexartitoi Ellines. (in Greek)

Assembly of the Republic of North Macedonia (2016). Pratenichki sostav [Parliamentary Composition]. Available

at: https://www.sobranie.mk/segashen-sostav-2016.nspx (accessed 15 May 2019). (in Macedonian)

Assembly of the Republic of North Macedonia (2018a). Zakon za ratifikacija na Konečnata spogodba za rešavanje na razlikite opišani vo rezoluciite 817 (1993) i 845 (1993) na Sovetot za bezbednost na Obedinetite nacii, za prestanuvanje na važnosta na Privremenata spogodba od 1995 godina i za vospostavuvanje na strateško partnerstvo meǵu stranite [Law on Ratification of the Final Settlement of Disputes Described in Resolutions 817 (1993) and 845 (1993) of the Security Council of the United Nations, for the Termination of the Interim Agreement of 1995godina i and Establishment of a Strategic Partnership Between the Parties]. Available at: https://www.sobranie.mk/materialdetails.nspx?materialId=ab0e1eaa-d9bf-4d82-b5b2-4d367eb2f96d (accessed 15 May 2019). (in Macedonian)

Assembly of the Republic of North Macedonia (2018b). Zakon za upotreba na jazicite [Law on Use of Languages]. Available at: https://www.sobranie.mk/materialdetails.nspx?materialId=1c6e42dc-d648-48b2-95d69d3f7a94ed51 (accessed 15 May 2019). (in Macedonian)

Assembly of the Republic of North Macedonia (2019). Predlog - Ustaven zakon za sproveduvanje na amandmanite od XXXIII do XXXVI na Ustavot na Respublika Makedonija [The Draft Constitutional Law for Implementation of Amendments from XXXIII to XXXVI of the Constitution of the Republic of Macedonia]. Available at: https://www.sobranie.mk/materialdetails.nspx?materialId=1df47a37-4b23-4440-b343-5042a895db16 (accessed 15 May 2019). (in Macedonian) 
Chung C. P. (2007) Resolving China's Island Disputes: A Two-Level Game Analysis. Journal of Chinese Political Science, vol. 12, no 1, pp. 49-70. Available at: https://doi.org.10.1007/s11366-007-9001-7.

European Commission (n. d.). North Macedonia. Available at: https://ec.europa.eu/neighbourhood-enlargement/

countries/detailed-country-information/north-macedonia_en (accessed 30 August 2019).

Hellenic Republic (n. d.). North Macedonia. Ministry of Foreign Affairs. Available at: https://www.mfa.gr/en/ blog/greece-bilateral-relations/north-macedonia/ (accessed 14 May 2019).

Hellenic Parliament (n. d.). Composition of Previous Terms. Available at: https://www.hellenicparliament. gr/en/Organosi-kai-Leitourgia/Olomeleia/SInthesi-Proigoumenon-Periodon-New/ (accessed 14 May 2019). Hellenic Parliament (2019). Pinakas periechomenon. Synedriasi XB'. Paraskeyi 25 Ianoyarioy 2019 [Table of Contents. XB Conference, 25 January 2019]. Available at: https://www.hellenicparliament.gr/UserFiles/a08fc2dd-61a9-4a83-b09a-09f4c564609d/es20190125.pdf (accessed 4 September 2019). (in Greek)

Hellenic Republic (2018). Final Agreement for the Settlement of the Differences as Described in the United Nations Security Council Resolutions 817 (1993) and 845 (1993), the Termination of the Interim Accord of 1995, and the Establishment of a Strategic Partnership Between the Parties. Ministry of Foreign Affairs. Available at: https://www.mfa.gr/images/docs/eidikathemata/agreement.pdf (accessed 30 August 2019).

Internal Macedonian Revolutionary Organization - Democratic Party for Macedonian National Unity (VMRO-DPMNE) (2017). Realno! Programma na VMRO-DPMNE 2017-2020 [Real! Programme of VMRODPMNE, 2017-2020]. Skopje: VMRO-DPMNE. (in Macedonian)

Koloskov E. (2013) Strana bez nazvaniya: vneshnepoliticheskij aspekt stanovleniya makedonskogo gosudarstva (1991-2001 z2.) [Country Without Name: Foreign Policy Aspect of the Foundation of the Macedonian State (19912001)]. Moscow: Institute of Slavic Studies of RAS. Available at: https://inslav.ru/publication/koloskov-estrana-bez-nazvaniya-vneshnepoliticheskiy-aspekt-stanovleniya-makedonskogo-0. (in Russian).

Kržalovski A. (2018) Referendum 2018. Scopje: Macedonian Center for International Cooperation (MCIC).

Kubicek P. (1997) Ethnic Conflict and Three-Level Games: Turks, Kurds, and Foreign Actors. International Negotiation, vol. 2, no 1, pp. 79-101. DOI: https://doi.org/10.1163/15718069720847870.

Mavromatidis F. (2010) The Role of the European Union in the Name Dispute Between Greece and FYR Macedonia. Journal of Contemporary European Studies, vol. 18, no 1, pp. 47-62. DOI: https://doi. org/10.1080/14782801003638703.

Mitsotakis K. (2019) Deyterologia toy Proedroy ths Neas Dimokratias k. Kyriakoy Mitsotaki sti syzitisi gia tin psifo empistosvnis sti Boyli [Reply of the President of the New Republic Kyriakos Mitsotakis to the Debate on the Vote of Confidence in Parliament]. Available at: https://nd.gr/deyterologia-toy-proedroy-tis-neasdimokratias-k-kyriakoy-mitsotaki-sti-syzitisi-gia-tin-psifo (accessed 4 September 2019). (in Greek)

North Atlantic Treaty Organization (NATO) (2019a). NATO Allies Sign Accession Protocol for the Future Republic of North Macedonia. Available at: https://www.nato.int/cps/ru/natohq/news_163078. htm? selectedLocale $=$ en (accessed 12 May 2019).

North Atlantic Treaty Organization (NATO). (2019b) Relations With the Republic of North Macedonia. Available at: https://www.nato.int/cps/en/natohq/topics_48830.htm (accessed 15 May 2019).

Nikovskij R. (2016) SSHA i nezavisimaya Makedoniya (1991-2013) [USA and Independent Macedonia (19932013)]. Moscow: Institute of Slavic Studies of RAS. (in Russian)

Panke D. (2013) Regional Power Revisited: How to Explain Differences in Coherency and Success of Regional Organizations in the United Nations General Assembly. International Negotiation, vol. 18, no 2, pp. 265-91. DOI: https://doi.org/10.1163/15718069-12341256.

Ponomareva E. (2010) Novye gosudarstva na Balkanah: Monografiya [New Balkan States: Monograph]. Moscow: MGIMO (U) MFA of Russia. (in Russian)

Putnam R.D. (1988) Diplomacy and Domestic Politics: The Logic of Two-Level Games. International Organization, vol. 42, no 3, pp. 427-60. DOI: https://doi.org/10.1017/S0020818300027697. 
Republic of Macedonia (2018). Referendum 2018. State Electoral Commission. Available at: https://referendum.sec.mk/Referendum/Results?cs=en-US\&r=r\&rd=r1\&eu=All\&m=All (accessed 26 October 2018).

Republic of North Macedonia (n. d.). Diplomatic Relations With Greece. Ministry of Foreign Affairs. Available at: http://www.mfa.gov.mk/index.php?option=com_content\&view=article\&id=241\&Itemid=396\&lang $=$ en (accessed 14 May 2019).

Social Democratic Union of Macedonia (SDSM) (2017). Programma za rabota na vladata 2017-2020 [Power Work Programme 2017-2020]. Skopje: SDSM. (in Macedonian)

Theodorakis S. (2019) Omilia tou Stavrou Theodoraki sti syzitisi gia tin kyrosi tou protokolou gia tin proschorisi tis Dimokratias tis Voreias Makedonias sto NATO [Speech of Stavros Theodorakis in the Debate on the Ratification of the Protocol on the Accession of the Republic of North Macedonia to NATO]. Available at: http:// topotami.gr/to-potami-den-thelei-valkania-me-mavres-trypes/ (accessed 4 September 2019). (in Greek)

Tzelepis M. (2019) Omilia M. Tzelepis Symfonia ton Prespon [Speech of M. Tzelepis About the Prespa Agreement]. Available at: http://pasok.gr/?p=23315 (accessed 4 September 2019). (in Greek)

Tziampiris A. (2012) The Macedonian Name Dispute and European Union Accession. Southeast European and Black Sea Studies, vol. 12, no 1, pp. 153-71. DOI: https://doi.org/10.1080/14683857.2012.661225. 